\title{
Simulation Study of Different Modulation Techniques for Three-Level Quasi-Z-Source Inverter
}

\author{
Carlos Roncero-Clemente (PhD student, University of Extremadura), Enrique Romero-Cadaval (Professor, \\ University of Extremadura), Oleksandr Husev (Research Fellow, Chernihiv State Technological University, Tallinn \\ University of Technology), Dmitri Vinnikov (Principal Research Fellow, Tallinn University of Technology).
}

\begin{abstract}
In this paper several modulation techniques for a three-level neutral-point-clamped quasi impedance source inverter are proposed and discussed. Mathematical descriptions with simulation results are presented for each modulation technique. Their advantages and disadvantages are shown and guidelines for further improvement are provided.
\end{abstract}

Keywords - Wind power generation, solar power generation, inverters, pulse width modulation, computer simulation.

\section{INTRODUCTION}

A three-level neutral-point-clamped (3L-NPC) inverter has a number of advantages, such as lower semiconductor voltage stress, lower required blocking voltage capability, decreased $d v / d t$, better harmonic performance, soft switching possibilities without additional components, higher switching frequency due to lower switching losses, and balanced neutralpoint voltage in comparison with the two-level voltage source inverter [1]. As a drawback, it has two additional clamping diodes per phase-leg and more controlled semiconductor switches per phase-leg than the two-level voltage source inverter. The 3L-NPC inverter can normally perform only the voltage buck operation. In order to ensure voltage boost operation an additional DC/DC boost converter should be used in the input stage [2-3].

To obtain buck and boost performance the focus is turned onto a quasi-Z-source inverter (qZSI). The qZSI was first introduced in [4]. The qZSI can buck and boost DC-link voltage in a single stage without additional switches.

The qZSI can boost the input voltage by introducing a special shoot-through switching state, which is the simultaneous conduction (cross conduction) of both switches of the same phase leg of the inverter. This switching state is forbidden for traditional voltage source inverters because it causes a short circuit of the DC-link capacitors. Thus, the qZSI has excellent immunity against the cross conduction of the top and bottom-side inverter switches. The possibility of using shoot-through eliminates the need for dead-times without having the risk of damaging the inverter circuit. The input voltage is regulated only by adjusting the shoot-through duty cycle. In addition, the qZSI has a continuous mode input current (input current never drops to zero), which makes it especially suitable for renewable energy sources (e.g. fuel cells, solar energy, wind energy etc.). The main drawback of the qZSI is its poor performance in the case of small loads and relatively low switching frequency. In these conditions the
qZSI starts to work in discontinuous conduction mode, which causes an over-boost effect and leads to instabilities [4-8].

A three-level neutral-point-clamped quasi-Z-source inverter (3L-NPC qZSI) proposed recently is a new modification of the qZSI (Fig. 1) [9][10]. The different states per leg in a 3L-NPC qZSI are shown in Table I. The new converter combines the advantages of the two topologies described above. But at the same time shoot-through switching state demands new approaches to modulation techniques in order to combine the boost factor, lower input current ripple and more capacitor voltage balance with the best possible output voltage quality.

This paper is devoted to the simulation of different shootthrough sinusoidal PWM techniques for the 3L-NPC qZSI that allow $50 \mathrm{~Hz}$ to be obtained as an output voltage frequency. It can be used in distributed energy resources, such as photovoltaic plants, fuel cells, etc.

\section{II.PRoblems of the Traditional SHOOT-Through MODUlation TECHNIQUE}

There are several pulse width modulation (PWM) techniques that could be applied for the 3L-NPC qZSI [4], [11]-[17].The core idea of these methods is presented in Fig. 2. All of them generate the shoot-through states when the output voltage is in the zero state $\left(U_{A B}=0\right)$ in order to maintain constant and not alter the normalized average voltage per switching period and the shoot-through states are carefully and centrally added to the active states that enable the number of higher harmonics to be kept to a minimum. Using these PWM techniques for the 3L-NPC qZSI, the $U_{A B}$ has only two zero states per period and shoot-through states can only be placed during these two intervals $([0, \pi / 4]$ and $[\pi, 5 \pi / 4])$.

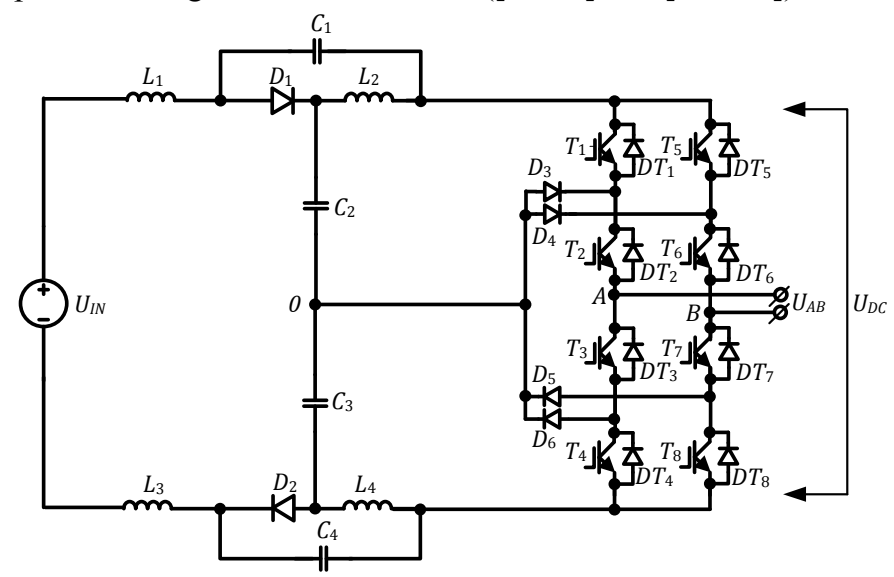

Fig. 1. 3L-NPC qZSI topology. 
TABLE I

DiFFERENT STATES PER BRANCH IN A 3-L NPC QZSI

\begin{tabular}{|c|c|c|}
\hline States & $\begin{array}{c}\text { Switching } \\
\text { Signals }\end{array}$ & $U_{A 0}$ \\
\hline & & \\
& & $T_{1} \mathrm{OFF}$ \\
$T_{2} \mathrm{OFF}$ & \\
\hline
\end{tabular}

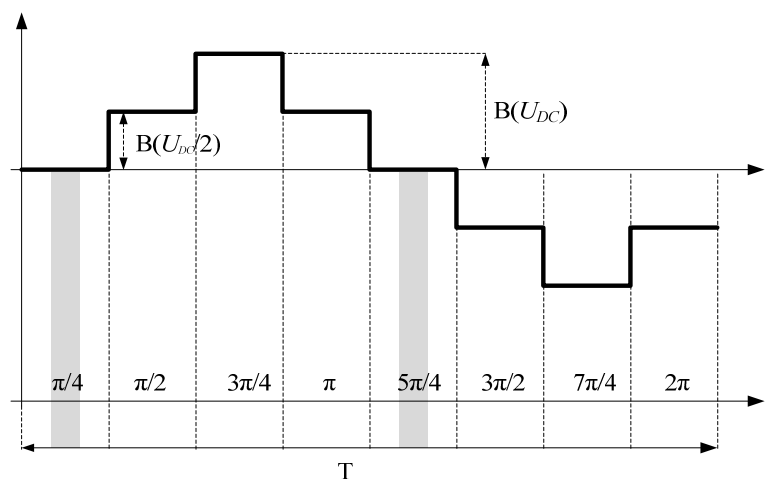

Fig. 2. Output voltage waveform of the traditional shoot-through PWM for a 3L-NPC qZSI.

These techniques present some problems, such as larger size of the passive elements, more input current ripple and capacitor voltage disbalance. It is due to the low shoot-through state frequency when the desired output voltage frequency is $50 \mathrm{~Hz}$. Furthermore, a higher THD is produced in comparison with that of the sinusoidal PWM (Fig. 3).

\section{NeW IMPROVED SHOOT-THROUGH MOdULATION TECHNIQUES FOR A 3L-NPC QZSI}

In the next section new methods will be proposed based on detailed explanations.

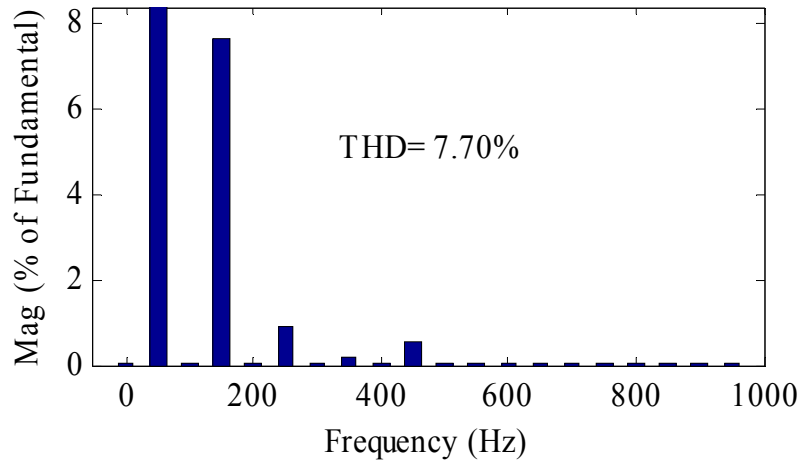

Fig. 3. Harmonic spectrum and THD of the filtered output voltage using the traditional modulation technique.

\section{A. Technique 1}

Fig. 4 shows a sketch of the proposed technique. Two modulating sinusoidal waves disphased by 180 degrees modulate each leg $\left(\bmod _{A}\right.$ and $\left.\bmod _{B}\right)$ and they are compared with two carrier waves, the first one with saw-tooth form (carrier $\left._{1}\right)$ and the second one is triangular $\left(\right.$ carrier $\left._{2}\right)$. The different states of $T_{1}, T_{2}, T_{5}$ and $T_{6}$ are generated and $T_{3}, T_{4}, T_{7}$ and $T_{8}$ have the complementary state of the other, respectively.

The shoot-through state is generated during zero states (1):

$$
U_{A B}=0,
$$

and it occurs when (2):

$$
U_{A 0}=U_{B 0} \text {. }
$$

Non-zero states $\left(U_{A B} \neq 0\right)$ occur when the condition (3) is present:

$$
S_{T 1}+S_{T 2}-S_{T 5}-S_{T 6}=0 .
$$

This condition is used in order to obtain the maximum value of the shoot-through state $\left(t_{s}\right)$ during a voltage output period (T) applying a not-operator to the condition (3).

The shoot-through duty cycle is defined as (4):

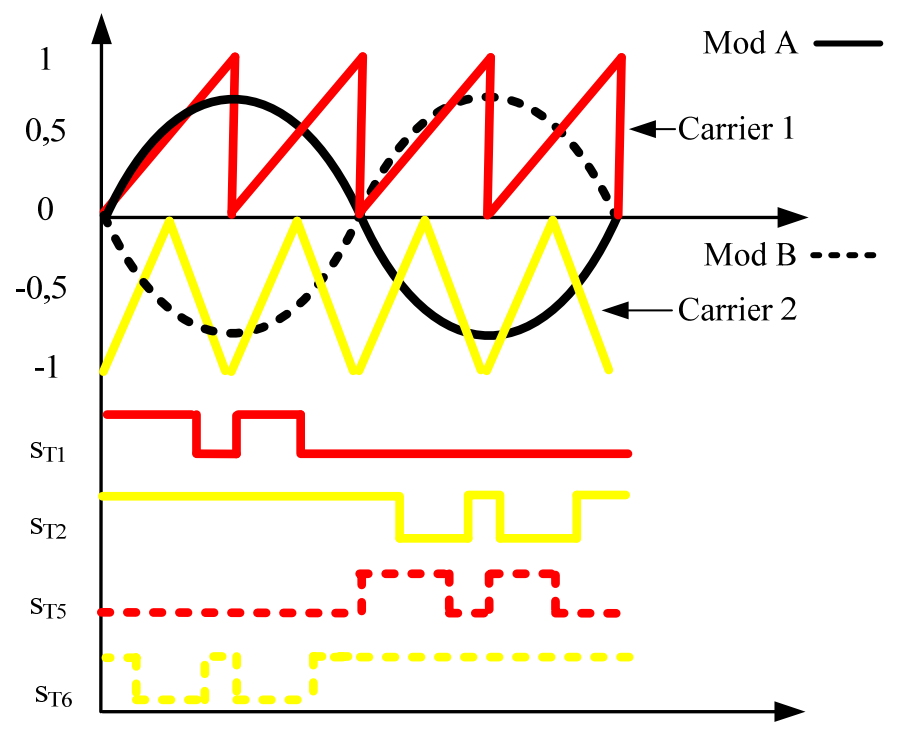

Fig. 4. Sketch of the proposed technique 1. 


$$
D_{s}=\frac{t_{s}}{T}
$$

and in the same way, it is possible to calculate the maximum voltage $\left(B\left(U_{d c}\right)\right.$ or $\left.-B\left(U_{d c}\right)\right)$ duty cycle $\left(D_{M}\right)(5)$ and the half voltage $\left(B\left(U_{d c}\right) / 2\right.$ or $\left.-B\left(U_{d c}\right) / 2\right)$ duty cycle $\left(D_{H}\right)(6)$ of the voltage $U_{A B}$ :

$$
\begin{aligned}
& D_{M}=\frac{t_{M}}{T}, \\
& D_{H}=\frac{t_{H}}{T} .
\end{aligned}
$$

In order to modify the $D_{S}$, the shoot-through factor $\left(F_{s-t}\right)$ is defined. This factor scales $\bmod _{A}$ and $\bmod _{B}$ and these new waves are compared with the two carriers, as shown in Fig. 5.

The obtained results of these comparisons are added or subtracted, respectively, according to (3) and a not-operator is used again in order to obtain the real shoot-through. Fig. 6 shows the values of the maximum value of the $\mathrm{S}-\mathrm{T}$ duty cycle

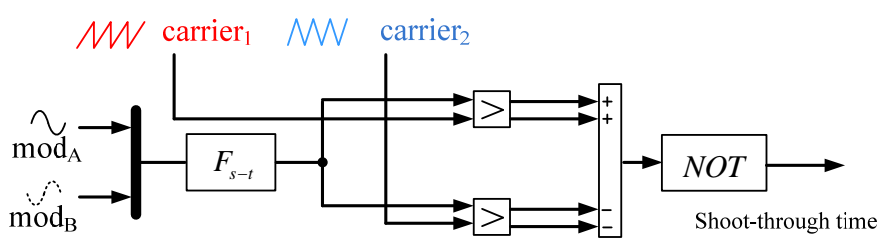

Fig. 5. Shoot-through factor and shoot-through time generation.

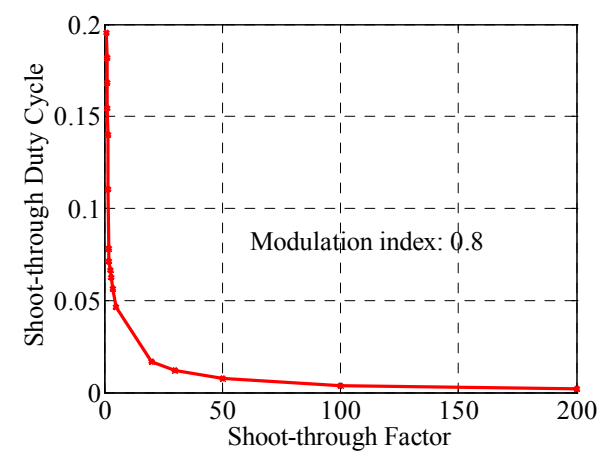

Fig. 6. Shoot-through factor and shoot-through duty cycle ratio.

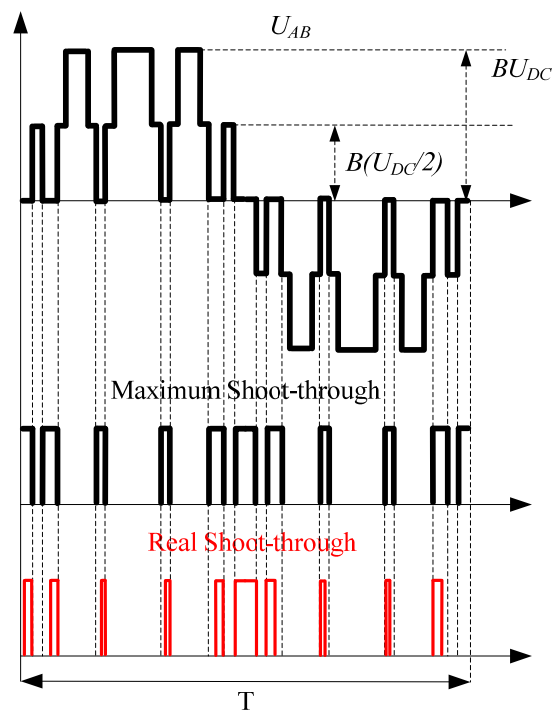

Fig. 7. Shoot-through states with the modulation technique 1.
$\left(D_{S}\right)$ versus $F_{S-t}$ for a fixed modulation index.

Operating in this way, the symmetry between the maximum value of the shoot-through and the real shoot-through time is assured (Fig. 7). Furthermore, we can see how the shootthrough states are generated during the whole output voltage period and the average voltage $U_{A B}$ is compensated through the increasing of $D_{M}$ and meanwhile the $D_{H}$ is decreased.

\section{B. Technique 2}

Fig. 8 shows a sketch of the proposed second technique. One modulating sinusoidal wave and four triangular carriers are compared in order to obtain the different states of $T_{1}, T_{2}, T_{5}$

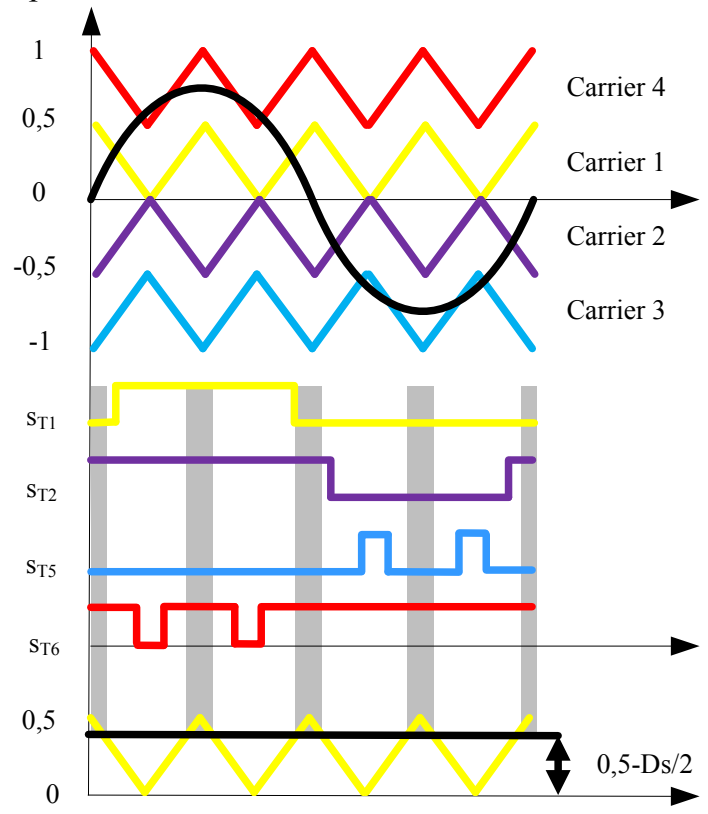

Fig. 8. Sketch of the proposed modulation technique 2 with uniformly distributed shoot-through states and constant width.

and $T_{6}$ and $T_{3}, T_{4}, T_{7}$ and $T_{8}$ have the complementary state of the other, respectively.

Carrier $_{1}$ is used to generate the shoot-through states in comparison with a constant value that includes the desired $D_{s}$ value. Operating in this way, uniformly distributed shootthrough states with the constant width during the whole output voltage period can be achieved.

The disadvantage of this technique is that the average voltage $U_{A B}$ is decreased because the average voltage in the leg $A\left(U_{A 0}\right)$ is decreased (during the positive semi-cycle) and increased (during the negative semi-cycle) when the shootthrough states are applied.

\section{Technique 3}

Technique 2 has been modified to compensate the average voltage $U_{A B}$ when the shoot-through states are applied, leg $B$ must compensate this situation through the change of the voltage $U_{B 0}$. Fig. 9 shows how we can obtain this compensation.

Also, it should be noted that an interesting aspect of the technique 2 is in the switching frequency of the transistors. During the mode without a shoot-through duty cycle, the amount of switching of the transistors leg A are lower than with leg B. 


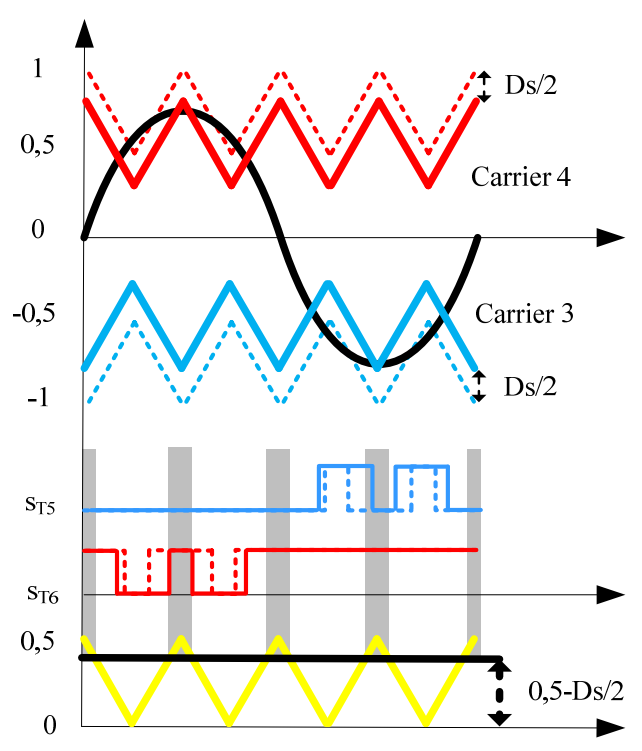

Fig. 9. Sketch of the proposed modulation technique 3.

\section{Simulation Results}

In order to verify the proposed techniques a comprehensive simulation study was performed in SimPowerSystems of Matlab/Simulink. The simulation circuit is presented in Fig. 10 and the parameters of the simulation are described in Table II.

\section{A. Technique 1}

Fig. 11 shows the obtained simulation results, listed from top to bottom: input current, voltage of the capacitors, DC-link voltage, output voltage $\left(U_{A B}\right)$, and voltage after the filter.

The input current peak is $74 \mathrm{~A}$ and the boost of the input voltage is not achieved due to the shoot-through states that are not uniformly distributed during all the output voltage period, as the DC-link voltage shows. It causes unsuitable working of the $\mathrm{qZ}$ stage, because the passive elements have been calculated for high frequency operation.
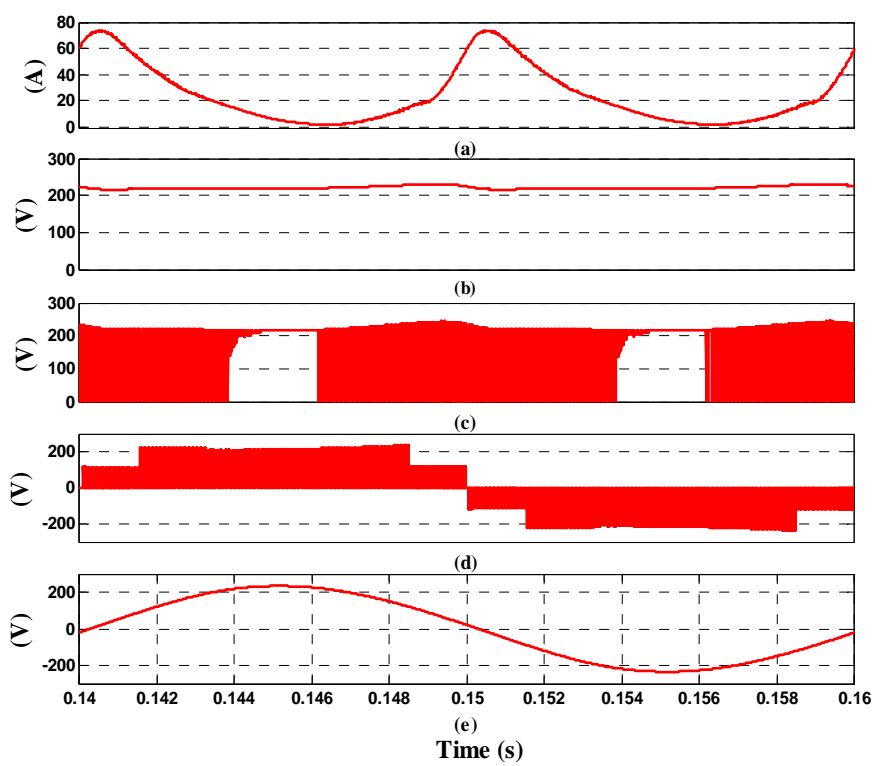

Fig. 11. Simulation result using modulation technique 1. (a) Input current. (b) Capacitor voltages $\left(C_{2}\right.$ and $\left.C_{3}\right)$. (c) DC-link voltage. (d) Output voltage. (e) Voltage after filter.

\section{B. Technique 2}

Fig. 12 shows the obtained simulation results, listed from top to bottom: input current, voltage of the capacitors, DC-link voltage, output voltage (UAB), and voltage after the filter.

Input current peak reaches $25 \mathrm{~A}$ due to the $\mathrm{qZ}$ stage that is working in an optimum mode because the appropriate shootthrough frequency is achieved. The DC-link voltage shows the uniform distribution and the constant width of the shootthrough states. The desired boost factor is not reached.

\section{Technique 3}

Fig. 13 shows the obtained simulation results, listed from top to bottom: input current, voltage of the capacitors, DC-link voltage, output voltage $\left(U_{A B}\right)$, and voltage after the filter. Input current peak reaches $28.5 \mathrm{~A}$. In this case, the desired boost voltage is achieved.
TABLE II

SIMULATION PARAMETERS

\begin{tabular}{|c|c|}
\hline Input voltage $U_{I N}$ & $220 \mathrm{~V}$ \\
\hline Inductors $L_{1} L_{2}, L_{3}, L_{4}$ & $96 \mathrm{mH}$ \\
\hline Inductor resistance $r_{L}$ & $0.5 \Omega$ \\
\hline Capacitors $C_{1}, C_{2}, C_{3}, C_{4}$ & $4 \mathrm{mF}$ \\
\hline Resistance load $R_{\text {load }}$ & $80 \Omega$ \\
\hline $\begin{array}{c}\text { Switching frequency } \\
\text { of carriers }\end{array}$ & $20 \mathrm{kHz}$ \\
\hline $\begin{array}{c}\text { Shoot-Through Duty } \\
\text { Cycle }\end{array}$ & 0.1667 \\
\hline Output frequency & $50 \mathrm{~Hz}$ \\
\hline Filter inductance & $4.4 \mathrm{mH}$ \\
\hline
\end{tabular}
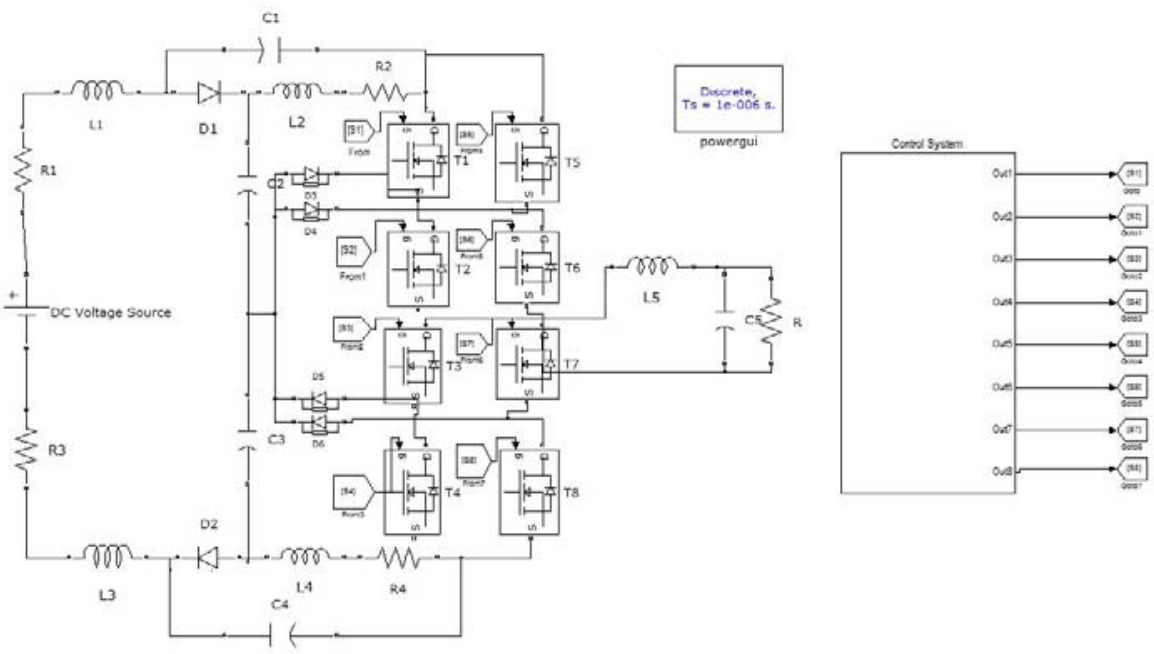

Fig. 10. Used simulation circuit with SimPowerSystem. 


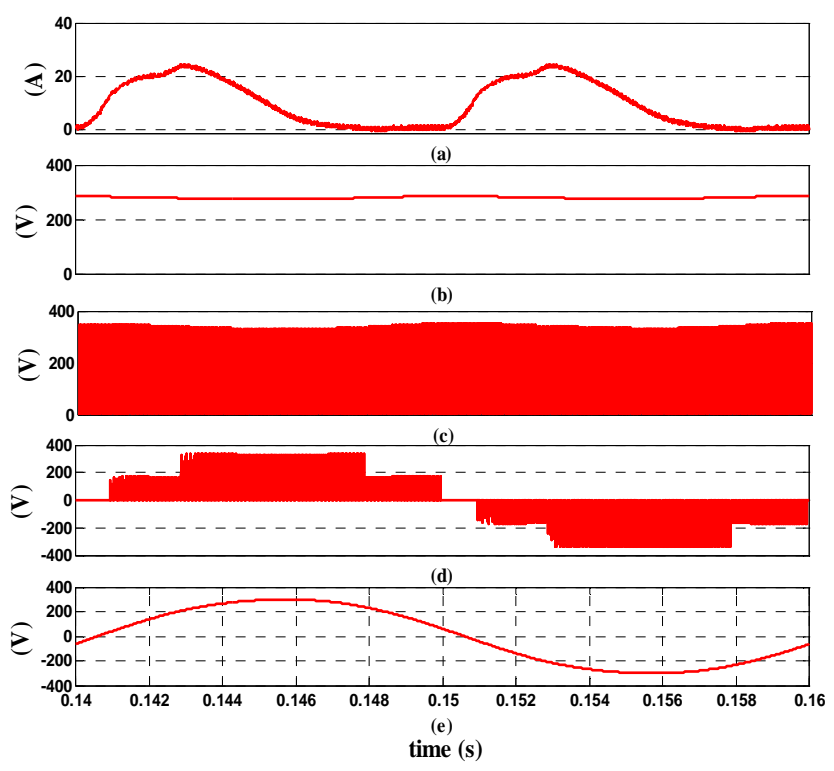

Fig. 12. Simulation result using modulation technique 2. (a) Input current. (b) Capacitor voltages $\left(C_{2}\right.$ and $\left.C_{3}\right)$. (c) DC-link voltage. (d) Output voltage. (e) Voltage after the filter.
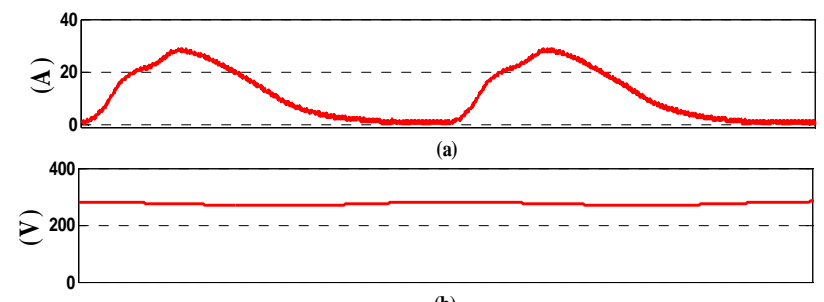

(b)

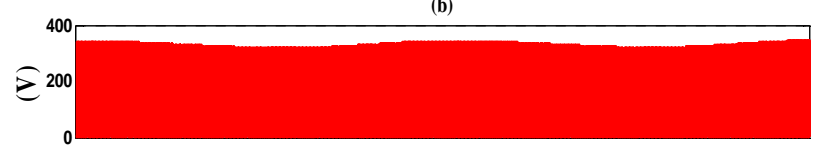

(c)
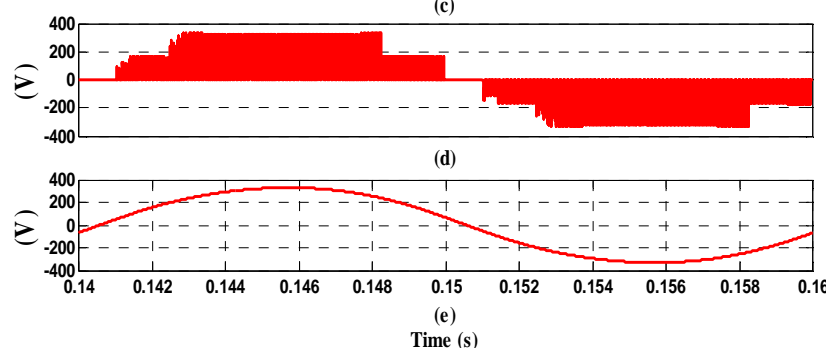

Fig. 13. Simulation result using modulation technique 3. (a) Input current. (b) Capacitor voltages $\left(C_{2}\right.$ and $\left.C_{3}\right)$. (c) DC-link voltage. (d) Output voltage. (e) Voltage after the filter.

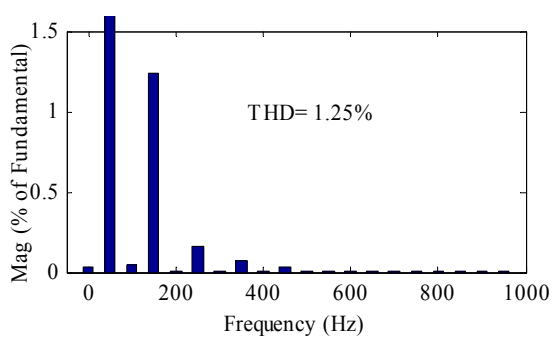

(a)

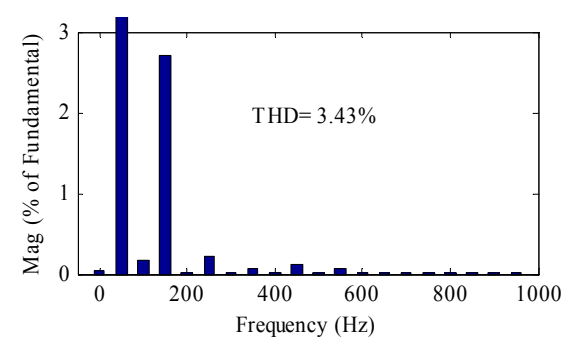

(b)

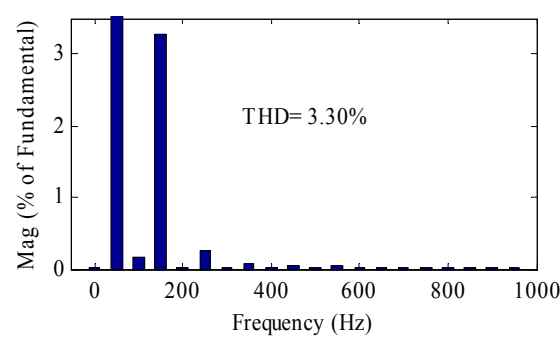

(c)

\section{ANALYTICAL COMPARISON}

In order to compare the exposed modulation techniques for a 3L-NPC qZSI, all the techniques are analyzed in this section. The comparison is based on four characteristics: output voltage quality, boost factor, input current ripple, and disbalance of the capacitor voltage.

\section{A. Output Voltage Quality}

Figs. 14 (a), (b) and (c) show the harmonic spectrum and the THD of the output voltage after the filter using technique 1 , technique 2 and technique 3 , respectively. With the three proposed techniques, we obtain proper values of the THD due to the PWM techniques are based on sinusoidal references, the symmetry between the shoot-through states is assured and the output $L-C$ filter is suitable. Modulation technique 1 has the smallest value. It is due to the Fs- $t$ that modifies the modulating sinusoidal waves and the fundamental component of the output voltage is increased.

\section{B. Boost Factor}

The boost factor is defined as (7):

$$
B=\frac{U_{D C}}{U_{I N}},
$$

and the obtained values using each modulation technique are shown in Table III.

$$
\text { TABLE III }
$$

OBTAINED VALUES USING EACH MODULATION TECHNIQUE

\begin{tabular}{|c|c|c|c|c|c|c|c|}
\hline $\begin{array}{c}\text { Modulation } \\
\text { technique }\end{array}$ & $\begin{array}{c}U_{I N} \\
(\mathrm{~V})\end{array}$ & $D_{s}$ & $F_{s-t}$ & $M$ & $\begin{array}{c}U_{d c} \\
(\mathrm{~V})\end{array}$ & $B$ & $\begin{array}{c}U_{p c c}^{\text {peak }} \\
(\mathrm{V})\end{array}$ \\
\hline Technique 1 & 220 & 0.166 & 1.6 & 0.75 & 216 & 0.98 & $235 \mathrm{~V}$ \\
\hline Technique 2 & 220 & 0.166 & - & 0.75 & 329 & 1.49 & $300 \mathrm{~V}$ \\
\hline Technique 3 & 220 & 0.166 & - & 0.75 & 333 & 1.51 & $325 \mathrm{~V}$ \\
\hline
\end{tabular}

In modulation technique 1 , the boost of the input voltage is not achieved because the shoot-through states are not uniformly distributed during the whole output voltage period and they have different pulse widths.

Fig. 14. After filter output voltage harmonic spectrum and THD using different modulation techniques. (a) Modulation technique 1. (b) Modulation technique 2. (c) Modulation technique 3. 
It causes unsuitable working of the $\mathrm{qZ}$ stage, because the passive elements have to be calculated for high frequency operation. Moreover, due to the non-linear connection between $F s$ - $t$ and $D_{s}$ due to the modification of the modulating sinusoidal waves, the control of the system is complicated.

In modulation technique 2 , the desired boost is reached because the shoot-through states are distributed with the constant width during the whole output voltage period and the $\mathrm{qZ}$ stage is working at a maximum frequency. Furthermore, using this proposed technique we can use the ratio between the modulation index $(M)$ and the maximum shoot-through duty cycle $D_{S \_M A X}(8)$ and the ratio between $B$ and $D_{s}(9)$ :

$$
\begin{aligned}
& D_{S_{-} M A X} \leq 1-M, \\
& B=\frac{U_{D C}}{U_{I N}}=\frac{1}{1-2 \cdot D_{S}} .
\end{aligned}
$$

These equations allow control algorithms to be developed in a closed loop, improving the 3L-NPC qZSI performance. However, the suitable value of $U_{p c c}^{\text {peak }}$ is not achieved because the average voltage $U_{A B}$ is decreased, due to the average voltage in the leg $A\left(U_{A 0}\right)$ is decreased (during the positive semi-cycle) and increased (during the negative semi-cycle) when the shoot-through states are applied.

In modulation technique 3 , the desired boost is reached as in modulation technique 2 . But in this case, the suitable value of $U_{p c c}^{\text {peak }}$ is achieved because leg $B$ compensates this situation through the change of the voltage $U_{B 0}$. Fig. 9 shows how to obtain this compensation. During the positive semi-cycle, leg $B$ has to produce $U_{B 0}=-U_{d c} / 2$ more time to restore the average voltage $U_{A B}$. This is produced through carrier $_{4}$ displacement that generates the pulses of $T_{6}$. During the negative semi-cycle the same situation is produced. Leg $B$ has to produce $U_{B 0}=$ $+U_{d c} / 2$ more time to restore the average voltage $U_{A B}$. This is produced through carrier $_{3}$ displacement that controls the pulses of $T_{5}$.

\section{Input Current Ripple}

Figs. 15, Fig. 16 and 17 show a detail of the input current using technique 1 , technique 2 and technique 3 , respectively.

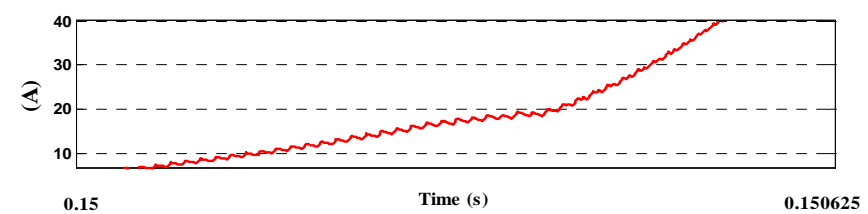

Fig. 15. Input current using modulation technique 1.

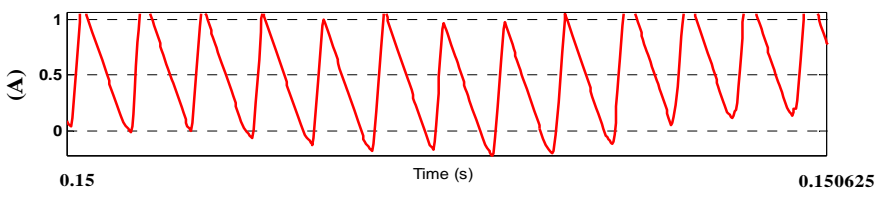

Fig. 16. Input current using modulation technique 2.
Using each modulation technique, we obtain $0.2 \mathrm{~A}, 1.25 \mathrm{~A}$ and $1.1 \mathrm{~A}$, respectively, as ripple values. A non-desired effect is produced in the case of modulation technique 2 because the input current works at discontinuous mode, which causes an over-boost effect and leads to instabilities.

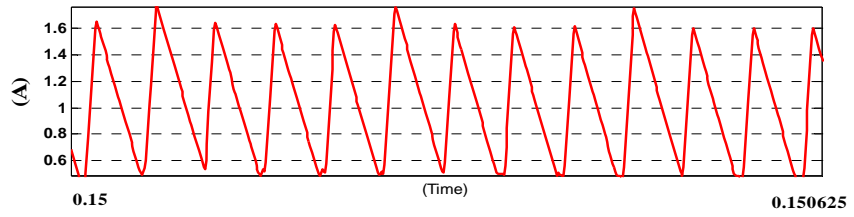

Fig. 17. Input current using modulation technique 3.

As described in section IV, in the case of modulation technique 1 , the input current peak is $74 \mathrm{~A}$ and it is the highest value. Also, in section III, a fluctuation at $100 \mathrm{~Hz}$ in all input current cases was observed. This phenomenon will be studied in detail in future experimental tests.

\section{Capacitor Voltage Disbalance}

Figs. 11, 12 and 13 show how the voltage at the capacitors is balanced, revealing a similar stable behavior.

\section{CONCLUSIONS}

This paper has proposed three shoot-through sinusoidal PWM techniques for the 3L-NPC qZSI that allow $50 \mathrm{~Hz}$ to be obtained as the output voltage frequency. Simulation using SymPowerSystems and Simulink of Matlab was used in our analysis. An analytical comparison between all three techniques was made based on output voltage quality, boost factor, input current ripple, and capacitor voltage balance.

Modulation technique 3 has shown the best performance and behaviour because the shoot-through states are uniformly distributed and with constant width during the whole output voltage period and the average output voltage is compensated through the displacement of the carriers.

\section{ACKNOWLEDGMENT}

This research work has been supported by Estonian Ministry of Education and Research (Project SF0140016s11) and Estonian Science Foundation (Grants ETF8538 and ETF8687) as well as by the Spanish institutions "Ministerio de Economía y Competitividad" and "Junta de Extremadura" and the funding of "Fondos FEDER".

\section{REFERENCES}

[1] Enrique Romero Cadaval, María Isabel Milanés Montero. "Cooperative converters in power electronic systems". 12th Biennial Baltic Electronics Conference. Tallinn, Estonia. 4-6 October 2010.

[2] F. Gao, P. C. Loh, F. Blaabjerg, D. M. Vilathgamuwa, "Dual Z-source inverter with three-level reduced common-mode switching", IEEE Transactions on industry applications, vol.43, no. 6, pp.1597-1608, 2007.

[3] P. C. Loh, S. W. Lim, F. Gao, F. Blaabjerg, "Three-level Z-source inverters using a single LC impedance network", IEEE Transactions on power electronics, vol. 22, no. 2, pp. 706-711, 2007.

[4] Anderson, J.; Peng, F.Z., "Four quasi-Z-Source inverters", in Proc. of IEEE Power Electronics Specialists Conference PESC'2008, pp. 27432749, June 15-19, 2008.

[5] F. Z. Peng, "Z-Source inverter", IEEE Transactions of Industry Applications, vol. 39, no. 2, pp.504-510, 2003. 
[6] R. Strzelecki, D. Vinnikov, "Models of the qZ-converters", Przeglad Elektrotechniczny, 86(6), $80-84,2010$.

[7] P. C. Loh, D. M. Vilathgamuwa, Y. S. Lai, G. T. Chua, Y. W. Li, "Pulse width modulation of Z-Source inverter", IEEE Transactions of Power Electronics, vol. 20, pp. 1346-1355, 2005.

[8] H. Rostami, D. A. Khaburi, "Voltage Gain Comparison of Different Control Methods of the Z-Source Inverter", International Conference on Electrical and Electronics Engineering, pp. 268-272, 2009.

[9] Ott, S.; Roasto, I.; Vinnikov, D.; , "Neutral point clamped quasiimpedance-source inverter," Compatibility and Power Electronics (CPE), 2011 7th International Conference-Workshop, vol., no., pp.348-353, 1-3 June 2011

[10] Ott, S.; Roasto, I.; Vinnikov, D.; Lehtla, T. (2011). Analytical and Experimental Investigation of Neutral Point Clamped Quasi-ImpedanceSource Inverter. Scientific Journal of Riga Technical University: Power and Electrical Engineering, 29, 113 - 118.

[11]F. Z. Peng, M. Shen, and Z. Qian, "Maximum boost control of the Zsource inverter," IEEE Trans. Power Electron., vol. 20, no. 4, pp. 833838, Jul./Aug. 2005.

[12]M.S. Shen, J. Wang, A. Joseph, F.Z. Peng, L.M. Tolbert, D.J. Adams, "Constant Boost Control of the Z-Source Inverter to Minimize Current Ripple and Voltage Stress," IEEE Trans. Ind. Appl., vol. 42, no. 3, pp. 770-778, May/June 2006.

[13]Roasto, I.; Vinnikov, D.; Jalakas, T.; Zakis, J.; Ott, S.; , "Experimental study of shoot-through control methods for qZSI-based DC/DC converters," Power Electronics Electrical Drives Automation and Motion (SPEEDAM), 2010 International Symposium on , vol., no., pp.29-34, 1416 June 2010

[14]Poh Chiang Loh; Vilathgamuwa, D.M.; Yue Sen Lai; Geok Tin Chua; Yunwei Li; , "Pulse-width modulation of Z-source inverters," Industry Applications Conference, 2004. 39th IAS Annual Meeting. Conference Record of the 2004 IEEE , vol.1, no., pp. 4 vol. 3-7 Oct. 2004

[15] Tae-Won Chun; Quang-Vinh Tran; Jung-Ryol Ahn; Jih-Sheng Lai; "AC Output Voltage Control with Minimization of Voltage Stress Across Devices in the Z-Source Inverter Using Modified SVPWM," Power Electronics Specialists Conference, 2006. PESC '06. 37th IEEE, vol., no., pp.1-5, 18-22 June 2006

[16]Poh Chiang Loh; Feng Gao; Blaabjerg, F.; Shi Yun Charmaine Feng; Kong Ngai Jamies Soon; , "Pulsewidth-Modulated Z-Source NeutralPoint-Clamped Inverter," Industry Applications, IEEE Transactions on, vol.43, no.5, pp.1295-1308, Sept.-oct. 2007

[17]Roasto, I.; Vinnikov, D.; , "Analysis and evaluation of PWM and PSM shoot-through control methods for voltage-fed qZSI based DC/DC converters," Power Electronics and Motion Control Conference (EPE/PEMC), 2010 14th International, vol., no., pp.T3-100-T3-105, 6-8 Sept. 2010

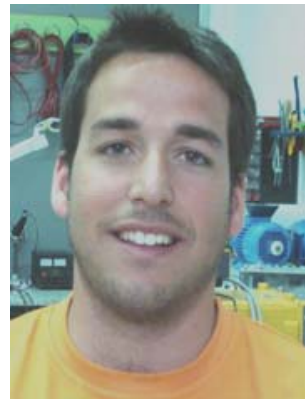

Carlos Roncero-Clemente (S'08) received the B.Sc. and M.Sc. degrees in electrical engineering from University of Extremadura, Spain, in 2006 and 2008, respectively, where he is currently working toward the Ph.D. degree. His Ph.D. thesis is devoted to the research and development of smart control for inverters. $\mathrm{He}$ is currently with the Power Electrical and Electronic Systems (PE\&ES) Research Group (http://peandes.unex.es). His research interests are power electronics in the power system, power quality, active power filters, renewable energy sources control, and smart grid.

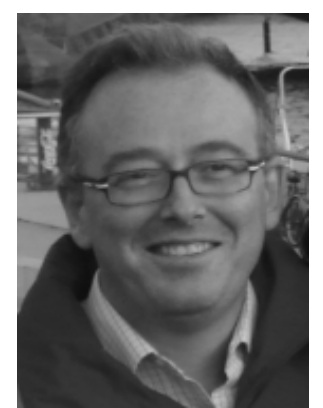

Enrique Romero-Cadaval (SM'10) was born in Villafranca de los Barros, Badajoz, Spain, in 1968. He received the M.Sc. degree in electronic industrial engineering from ICAI, Universidad Pontificia de Comillas, Madrid, Spain, in 1992 and the Ph. D. degree from the Universidad de Extremadura, Badajoz, Spain, in 2004. He is a full Professor in power electronics at the Universidad of Extremadura, Badajoz, Spain. He is currently with the Power Electrical and Electronic Systems (PE\&ES) Research Group (http://peandes.unex.es). His research interests are power electronics in the power system, power quality, active power filters, renewable energy sources control, smart grids, and electrical vehicles.

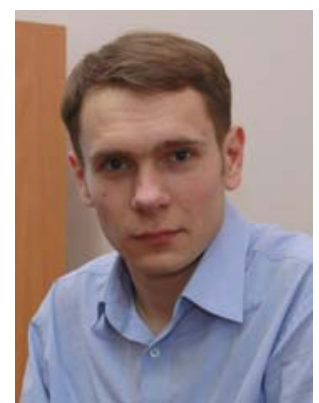

Oleksandr Husev received the B.Sc, and M.Sc. degrees in industrial electronics from Chernihiv State Technological University, Chernihiv, Ukraine, in 2007 and 2008 respectively, where he is currently working toward the $\mathrm{PhD}$ degree. His $\mathrm{PhD}$ thesis is devoted to active power filters and development of a control system based on artificial intellect.

$\mathrm{He}$ is assistant of the Department of Industrial Electronics, Chernihiv State Technological University and currently cooperates with the Department of Electrical Drives and Power Electronics, Tallinn University of Technology. He has over 20 publications and is the holder of several patents.

His research interests are in control systems for power electronic converters based on a wide range of algorithms, including modeling, design, and simulation.

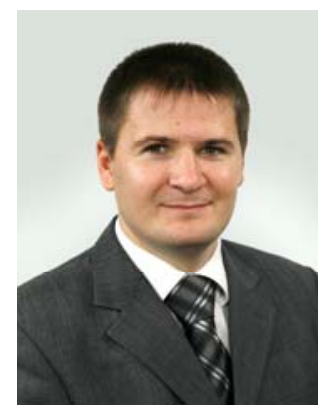

Dmitri Vinnikov received the Dipl.Eng, M.Sc. and Dr.Sc.techn. degrees in electrical engineering from Tallinn University of Technology, Tallinn, Estonia, in 1999, 2001 and 2005 , respectively.

$\mathrm{He}$ is presently a Senior Researcher in the Department of Electrical Drives and Power Electronics, Tallinn University of Technology. $\mathrm{He}$ has authored more than 100 published papers on power converters design and development and is the holder of several Utility Models in this application field. His research interests include switch mode power converters, modeling and simulation of power systems, applied design of power converters and control systems and application, and development of energy storage systems. 